\title{
Yield, antioxidant activity and shelf-life of cauliflower inflorescences under drought stress and foliar spraying of selenium
}

\section{Produtividade, atividade antioxidante e vida de prateleira de inflorescências de couve-flor sob estresse hídrico e aplicação foliar de selênio}

\author{
Tiago Luan Hachmann ${ }^{*}(\mathbb{D})$, Roberto Rezende ${ }^{2}$ D, Paula Toshimi Matumoto-Pintro2 (D), Reni Saath² (D), \\ Fernando Antônio Anjo² (D), Cláudia Salim Lozano Menezes² (iD
}

\author{
1'Instituto Paranaense de Assistência Técnica e Extensão Rural/EMATER, Campo Mourão, PR, Brasil \\ 2Universidade Estadual de Maringá/UEM, Maringá, PR, Brasil \\ *Corresponding author: tiagohach@gmail.com \\ Received in July 20, 2019 and approved in November 6, 2019
}

\begin{abstract}
The ability of antioxidant compounds in vegetables to prevent disease is important for the pharmaceutical and food industries. In addition, water stress can enhance the existing antioxidant capacity of plants. As such, this study aimed to assess the effect of different irrigation depths and selenium application on the postharvest characteristics of cauliflower. A randomized block design was used in a $3 \mathrm{x}$ 2 factorial scheme, with four repetitions. The first factor consisted of three irrigation depths with regulated deficit irrigation (RDI): severe ( $50 \% \mathrm{ETc}$ ) and moderate RDI (75\% ETc) and complete irrigation (100\% ETc), performed after inflorescence initiation, and the second of foliar spraying of selenium (with and without the element). Selenium application increased cauliflower yield under moderate RDI and no water/drought stress. Moderate RDI was the most effective strategy for maintaining yield and increasing the antioxidant capacity and phenolic compound content of cauliflower. Foliar spraying of selenium raised total polyphenol content under drought stress. Severe RDI extended the shelf life of cauliflower florets.
\end{abstract}

Index terms: Quality; sodium selenate; regulated irrigation deficit; postharvest.

\begin{abstract}
RESUMO
A capacidade de compostos antioxidantes presentes em hortaliças prevenir doenças é importante para as indústrias farmacêutica e alimentícia. Somado a isso, o estresse hídrico pode aumentar a capacidade antioxidante já existente em plantas. Baseado nisso, um experimento foi conduzido com o objetivo de avaliar o efeito de diferentes lâminas de irrigação em função da aplicação de selênio, nas características pós-colheita da couve-flor. O delineamento experimental utilizado foi de blocos ao acaso, em esquema fatorial $3 \times 2$, com quatro repetições. O primeiro fator foi constituído por três manejos da irrigação com déficit hídrico regulado (déficit hídrico regulado severo (50\% da ETc), déficit hídrico regulado moderado (75\% da ETc) e irrigação completa (100\% da ETc), aplicados após o início da formação das inflorescências) e o segundo pela aplicação foliar de selênio (com aplicação e sem aplicação do elemento). A aplicação foliar de selênio proporcionou aumento de produtividade das plantas sob condição de déficit hídrico regulado moderado (75\% da ETc) e sem déficit hídrico (100\% da ETc). O cultivo sob déficit hídrico regulado moderado (75\% da ETc) foi mais adequada por manter a produtividade e elevar a capacidade antioxidante e do teor de compostos fenólicos. A aplicação foliar de selênio aumentou o teor de polifenóis totais sob condição de estresse hídrico. A aplicação de estresse hídrico regulado severo (50\% da ETc) proporcionou maior vida de prateleira aos floretes de couve-flor.
\end{abstract}

Termos para indexação: Qualidade; selenato de sódio; déficit hídrico regulado; pós-colheita.

\section{INTRODUCTION}

The need to increase agricultural production to cater to rising populations while the means to do so (land, water and input) grow increasingly scarce is a global dilemma. This has prompted the adoption of sustainable intensification (SI), defined as an agricultural system where yields are increased or maintained while optimizing the necessary resources (Pretty et al., 2018).

The irrigated area worldwide covers an estimated $17 \%$ of the total arable land and accounts for more than $40 \%$ of all food consumed. Production in irrigated areas is 2.5-fold higher than in dry regions. In Brazil, every hectare of irrigated land is equivalent to three hectares of dry terrain in terms of actual yield, and seven from an 
economic perspective (Paulino et al., 2011). Their high sensitivity to drought stress means vegetable crops are among those that most benefit from irrigation.

Regulated deficit irrigation (RDI) has been studied as an alternative for increasing the efficiency of production systems. This technique involves limiting irrigation during less drought-sensitive growth stages with little or no impact on yield and quality (Romero-Trigueros et al., 2017), and has been touted as key technology in reducing global water consumption (Chai et al., 2016).

Interest in RDI has largely focused on its potential to save water or control excessive growth (Costa; Ortuño; Chaves, 2007). Vegetable farming using RDI lowers water consumption and ensures better postharvest quality in terms of shelf life and bioactive compound content, without necessarily reducing yields (Zaicovski et al., 2008).

Preharvest drought stress improved the postharvest quality of broccoli, with better retention of green color in the floret and a longer shelf life, likely due to greater cytokinin biosynthesis (Zaicovski et al., 2008). These results suggest that reducing the irrigation depth may enhance antioxidant activity and help preserve compounds beneficial to human health, including chlorophylls, carotenoids, phenolic compounds, ascorbic acid and folates.

Environmental factors such as light, temperature, nutrition and water supply may influence the chemical composition and concentration of bioactive substances in vegetables, which directly affects antioxidant activity (Schreiner et al., 2013). Irrigation and fertilization are the main management practices that influence the biosynthesis of antioxidant compounds (Bogale et al., 2016).

With respect to fertilization, selenium application has been studied as a means of increasing concentrations of beneficial compounds in vegetables. Selenium has a proven effect on plant-water relations, gas exchange and increased antioxidant activity (Nawaz et al., 2015). A change in phenolic compound content was observed in response to selenium in broccoli (Finley et al., 2005), lettuce (Ríos et al., 2008) and tomato (Schiavon et al., 2013), whereby phenolic compound and flavonoid accumulation varied as a function of selenium dose and the phenological stage in which it was applied.

The aim of this study was to assess the effects of selenium application and regulated deficit irrigation on the bioactive compounds, shelf life and yield traits of a summer cauliflower (Brassica oleracea var. brotrytis) crop.

\section{MATERIAL AND METHODS}

The study was conducted from November 2017 to April 2018, in Maringá, Paraná (PR) state, Brazil (23⒉ ' S, $51^{\circ} 57^{\prime} \mathrm{W}$ and altitude of $542 \mathrm{~m}$ ). The crop was grown in a greenhouse with an arched roof, measuring $7 \times 25 \mathrm{~m}$ and $3.5 \mathrm{~m}$ high. The roof was covered with $150 \mu \mathrm{m}$ thick anti-UV diffused low density polyethylene (LDPE) film and the sides with $40 \%$ white shade cloth.

A randomized block design was used in a $3 \times 2$ factorial scheme, with four repetitions. The first factor consisted of three irrigation depths with regulated deficit irrigation (RDI): severe (50\% ETc) and moderate RDI $(75 \% \mathrm{ETc})$ and complete irrigation $(100 \% \mathrm{ETc})$, performed after inflorescence initiation, and the second of foliar spraying of selenium (with and without the element).

Forty-eight plots were prepared inside the greenhouse, measuring $3 \mathrm{~m}$ long, $0.5 \mathrm{~m}$ wide and $0.25 \mathrm{~m}$ high. Base dressing was performed based on soil analysis and the recommendations of Trani (1996), by turning the soil with a rotary hoe. The genetic material used was the 'Verona' cultivar, a summer hybrid. Seedlings were produced in 128-cell expanded polystyrene trays containing commercial substrate. The trays were placed inside the greenhouse until transplanting, which occurred when plants displayed three to four true leaves. Six plants were transplanted per subplot and the four center plants were assessed.

Crop evapotranspiration (ETc) was determined using three constant water table lysimeters installed in the greenhouse. Two seedlings were transplanted into the lysimeters, spaced $0.5 \mathrm{~m}$ apart, so that the water extracted by the plants was automatically replenished by the system. Readings and water replacement in the tank were performed at 8 a.m. every day, followed by the treatments using different irrigation depths. During the vegetative stage, the same irrigation depth $(100 \% \mathrm{ETc})$ was used in all the treatments.

The deficit irrigation treatments were applied by drip irrigation when plants entered the reproductive stage (head formation). Drip irrigation was performed via high density polyethylene tubing installed in each plot, equipped with 12 pressure compensating drippers $\left(4 \mathrm{~L} \mathrm{~h}^{-1}\right.$ flow rate) spaced $0.25 \mathrm{~m}$ apart.

Selenium was applied at the same times as the irrigation depth treatments, with the first application after inflorescence emergence, the second seven days later, and the third fourteen days after initial spraying. Foliar spraying of selenium was performed using a backpack sprayer, with a $100 \mathrm{ppm}$ sodium selenite solution at 10 ML per application. 
Harvesting was carried out in one day, 72 days after transplanting, when most of the inflorescences were compact and well-developed, measuring approximately $20-25 \mathrm{~cm}$. Next, the inflorescences were weighed to determine the head fresh weight (HFW), then cut into smaller pieces and oven dried at $65 \pm 5{ }^{\circ} \mathrm{C}$ until constant weight to obtain the head dry weight (HDW). Yield was calculated based on HFW data.

For postharvest analyses, the inflorescences were cut into florets and four were randomly chosen for color assessment with a Minolta color meter (Chroma Meter CR-400, Minolta, USA). Color was evaluated using the CIELAB color space, where $\mathrm{L}^{*}$ represents lightness from black to white, $\mathrm{a}^{*}$ from green to red, and $\mathrm{b}^{*}$ from blue to yellow. The $a^{*}$ and $b^{*}$ coordinates were used to calculate $\mathrm{h}^{\mathrm{o}}$ (hue angle) and $\mathrm{C}^{*}$ (chroma), based on the following formulas: $\mathrm{h}^{0}=\tan ^{-1}\left(\mathrm{~b} * \mathrm{a}^{*}\right)$ and $\mathrm{C}^{*}=(\mathrm{a} * 2+\mathrm{b} * 2) 1 / 2$, respectively.

Four additional florets from each treatment were assessed for texture using the compression test. To that end, the florets (20 to $30 \mathrm{~g}$ ) were tested in a texture analyzer (CT3, Brookfield, USA) equipped with a cylinder probe (TA10) and programmed to operate at a cutting distance of $15 \mathrm{~mm}$, with a trigger load of 0.1 $\mathrm{N}$ and $5 \mathrm{~mm} / \mathrm{s}$ test speed. Firmness was expressed in newtons $(\mathrm{N})$.

For the remaining analyses, florets were placed in a fruit centrifuge to obtain an aqueous extract. The $\mathrm{pH}$ was measured directly in the extract using a calibrated $\mathrm{pH}$ meter. Soluble solids content was determined in an aliquot of extract using a digital refractometer and expressed in ${ }^{\circ}$ Brix.

Titratable acid was analyzed by titration with sodium hydroxide, according to the methodology proposed by the Adolfo Lutz Institute (2008). To that end, $40 \mathrm{~mL}$ of water was added to $10 \mathrm{~mL}$ extract, followed by three drops of phenolphthalein solution. Titration was then performed with $0.1 \mathrm{M}$ sodium hydroxide and results expressed in $\mathrm{g}$ of malic acid/100 g sample.

For polyphenol content and antioxidant activity analyses, antioxidants were extracted from the inflorescences according to the protocol of Saraiva et al. (2019), with some modifications, by adding $9 \mathrm{~mL}$ methanol to $1 \mathrm{~mL}$ of the juice extracted in a centrifuge. The resulting solution was homogenized in a vortex test tube shaker for 10 seconds, agitated for 10 minutes, and then centrifuged for another 10 minutes at $3000 \mathrm{rpm}$ for complete phase separation. The hydromethanol layer (top) was separated with a Pasteur pipette and placed in labelled PVC test tubes.
Total polyphenol content was determined based on the method developed by Folin and Ciocalteu (1927) and adapted by Singleton, Orthofer and Lamuela (1999). Initially, a gallic acid curve was built and $125 \mu \mathrm{L}$ of the methanol extract, $125 \mu \mathrm{L}$ Folin's reagent and 2250 $\mu \mathrm{L}$ sodium carbonate were placed in test tubes and homogenized for 10 seconds in a test tube shaker (vortex), then transferred to cuvettes. The cuvettes were left to rest in the dark for 30 minutes and absorbance was then read at $725 \mathrm{~nm}$ in a spectrophotometer. Results were expressed in $\mathrm{mg}$ of gallic acid equivalent $/ \mathrm{mL}$ of extract.

Total antioxidant activity of the inflorescences was assessed by DPPH (2,2-diphenyl-1-picrylhydrazyl) free radical scavenging and the ferric reducing antioxidant power (FRAP) assay. The first assay evaluates the ability of antioxidants present in the samples to scavenge the stable free radical (DPPH). To that end, a $150 \mu \mathrm{L}$ aliquot of the extract was transferred to a cuvette and added with $2.85 \mathrm{~mL}$ DPPH free radical solution. After 30 minutes, absorbance was read at $515 \mathrm{~nm}$ in a spectrophotometer. Antioxidant activity was determined according to the methodology described by Brand-Williams, Cuvelier and Berset (1995).

Ferric reducing antioxidant power (FRAP) was determined according to the published protocol of $\mathrm{Zhu}$ et al. (2002). A $250 \mu \mathrm{L}$ aliquot of each of the samples was pipetted into Falcon test tubes, protected from light, and added with $1.25 \mathrm{~mL}$ phosphate buffer and $1.25 \mathrm{~mL}$ of $1 \%$ potassium ferricyanide. The test tubes were homogenized for 10 minutes in a test tube shaker (vortex), incubated in a water bath for 20 minutes at $50{ }^{\circ} \mathrm{C}$, allowed to cool for 5 minutes and then added with $1.25 \mathrm{~mL}$ of $10 \%$ trichloroacetic acid (TCA). The solutions were centrifuged for 10 minutes at $3000 \mathrm{rpm}$ and $2.5 \mathrm{~mL}$ of the supernatant was removed and placed in test tubes protected from light. Absorbance was read at $700 \mathrm{~nm}$ in a spectrophotomer, at which time $0.5 \mathrm{~mL}$ iron (III) chloride was added to the test tubes.

In order to evaluate shelf life, five florets were selected from each treatment and weighed on day one to determine the initial fresh weight of each floret. Five days later the same florets were weighed again to determine weight loss and assessed for texture and color. The same procedure was performed 10,15 and 20 days after the start of the experiment.

Data were submitted to analysis of variance and means compared by Tukey's test $(\mathrm{p}<0.05)$, using Sisvar software (Ferreira, 2011).

\section{RESULTS AND DISCUSSION}

Interaction was observed between irrigation depth and selenium application for head fresh (HFW) 
and dry weight (HDW), yield, $\mathrm{pH}$, titratable acidity, antioxidant activity (DPPH and FRAP) and total polyphenols. The remaining factors were analyzed individually (Table 1).

Under moderate RDI (RDI moderate $_{\text {) and no }}$ drought stress (no RDI), head fresh weight and yield increased with selenium foliar spraying. Habibi et al. (2013) also recorded higher growth of spring barley with selenium application. Sattar et al. (2019) also documented that selenium application under drought stress in wheat produced a remarkable improvement in growth parameters. The participation of selenium in osmoregulation and ensuring optimal water balance in cells are considered the primary mechanisms associated with its protective effect under drought conditions (Sieprawska; Kornaś; Filek, 2015). Drought stress reduced the gas exchange rate in most plants and selenium significantly increased net photosynthesis $\left(\mathrm{P}_{n}\right)$ and stomatal conductivity $\left(\mathrm{g}_{s}\right)$ under normal and restricted irrigation, which may be related to the positive role of selenium in protecting the photosynthetic apparatus (Nawaz et al., 2015).

Nawaz et al. (2015) found that foliar spraying of selenium increased relative water content under normal irrigation and moderate drought stress. Habibi et al. (2013) recorded a higher relative water content in barley plants treated with selenium, which they attributed to its effect on improving membrane integrity and reducing photooxidation.

Selenium application increased head dry weight under RDI ${ }_{\text {severe }}$, suggesting different mechanisms of action for selenium as a function of drought stress severity. According to Nawaz et al. (2015), the effect of selenium in mitigating environmental stress has yet to be fully elucidated, although its positive influence on plant-water relations, gas exchange, osmoprotective activities and antioxidant properties is well documented.

Yield did not decline under RDI severe $(50 \%$ ETc) and $\mathrm{RDI}_{\text {moderate }}(75 \% \mathrm{ETc})$ when compared to that obtained under normal irrigation (no RDI). It may have remained stable despite drought stress because moderate RDI was only implemented after most of the leaves had fully expanded, altering plant-water relations without affecting the photosynthetic area. The relationship between photosynthesis and transpiration rates changed under $\mathrm{RDI} I_{\text {moderate }}$, with higher transpiration rates resulting in more efficient photosynthesis (Chai et al., 2016). Cirillo et al. (2014) found that Bougainvillea growth declined under deficit irrigation, although the precise effect depends on its severity and when it was implemented.

$\mathrm{Xu}$ and Leskovar (2014) also found no significant difference between irrigation depths of $75 \%$ and $100 \%$ ETc for head fresh weight and yield in cauliflower plants. According to Seidel et al. (2017), irrigating white cabbage until a few days after the onset of head formation and two to three weeks before harvesting results in the same yield as that obtained with irrigation throughout the cycle. According to the authors, deficit irrigation reduces water consumption without compromising yield. These findings could contribute to lowering the use of resources without reducing yield (Pretty et al., 2018).

Table 1: Head fresh and dry weight and yield of cauliflower submitted to selenium application under different irrigation depths.

\begin{tabular}{|c|c|c|c|c|c|c|c|c|c|}
\hline \multicolumn{4}{|c|}{ HEAD FRESH WEIGHT } & \multicolumn{3}{|c|}{ HEAD DRY WEIGHT } & \multicolumn{3}{|c|}{ YIELD } \\
\hline \multicolumn{4}{|c|}{--- g --- } & \multicolumn{3}{|c|}{--- g --- } & \multicolumn{3}{|c|}{--- Mg ha-1 --- } \\
\hline Irrigation depth & $-\mathrm{Se}$ & $+\mathrm{Se}$ & Mean & $-\mathrm{Se}$ & $+\mathrm{Se}$ & Mean & $-\mathrm{Se}$ & $+\mathrm{Se}$ & Mean \\
\hline $\mathrm{RDI}_{\text {severe }}$ & $1168.17 a A$ & 1152.79aB & 1160.48 & $94.41 \mathrm{bA}$ & $131.28 \mathrm{aA}$ & 94.59 & $22.90 \mathrm{aA}$ & $23.05 \mathrm{aB}$ & 23.21 \\
\hline $\mathrm{RDI}_{\text {moderate }}$ & $1145.46 \mathrm{bA}$ & $1267.50 \mathrm{aAB}$ & 1206.48 & $84.63 a A$ & $96.60 \mathrm{aB}$ & 90.65 & $22.90 \mathrm{bA}$ & $25.35 a A B$ & 24.12 \\
\hline No RDI & $1177.00 \mathrm{bA}$ & $1430.01 \mathrm{aA}$ & 1326.00 & 87.94aA & $94.78 \mathrm{aB}$ & 109.61 & $23.54 \mathrm{bA}$ & $29.50 a A$ & 26.52 \\
\hline Mean & 1163.54 & 1283.57 & 1230.99 & 89.00 & 107.57 & 98.28 & 23.27 & 25.96 & 24.61 \\
\hline CV(\%) & & 7.69 & & & 14.06 & & & 7.69 & \\
\hline
\end{tabular}

*The same lower case letters do not differ for selenium application and the same upper case letters do not differ for irrigation depth according to Tukey's test $(P \leq 0.05)$. (-Se) - without selenium application; (+ Se) foliar spraying of selenium using 100 ppm sodium selenite solution applied three times during the growth cycle; $\mathrm{RDI}_{\text {severe }}$ - severe regulated drought irrigation (50\% $\mathrm{ETC}$ ); $\mathrm{RDI}_{\text {moderate }}$ - moderate regulated drought irrigation (75\% ETc); No RDI - no water restrictions (100\% ETc). 
Yield was higher in treatments with moderate and no RDI when selenium was applied, demonstrating that selenium does not increase yield under severe drought stress, but does under moderate and no drought stress. This may be related to the antioxidant activity of cauliflower plant when treated with selenium. Selenium application improved antioxidant activity (FRAP) under moderate $\left(\mathrm{RDI}_{\text {moderate }}\right)$ and no RDI (Table 2), but not under severe water deficit (RDI severe ). Wang et al. (2014) concluded that heavy metal stress decreased antioxidant activity (due to protein damage), whereas selenium increased it, albeit under less stress. Photosynthesis declines when the harmful effects of drought stress are not offset. Rho et al. (2012) observed a 30\% reduction in photosynthesis in plants under severe drought stress $(50 \%$ ETc) compared to daily irrigated plants $(100 \%$ $\mathrm{ETc})$.

Severe drought stress is generally accompanied by a significant decline in the maximum photosynthetic efficiency of photosystem II and greater synthesis of enzymatic and non-enzymatic antioxidants, suggesting the onset of oxidative stress (Sieprawska; Kornaś; Filek, 2015). Despite obtaining lower yields, Zegbe, Behboudian and Clothier (2006) reported that water conservation and better fruit quality compensate for reductions in fresh or dry weight, particularly when water is expensive.

Selenium foliar spraying resulted in high $\mathrm{pH}$ values under severe and moderate RDI (Table 2). Costa, Ortuño and Chaves (2007) observed that drought increased $\mathrm{pH}$ in tomatoes. With respect to the effect of selenium at each irrigation depth, $\mathrm{pH}$ was higher in the $\mathrm{RDI}_{\text {severe }}$ treatment with selenium foliar spraying. Under optimal irrigation conditions (no RDI), the highest $\mathrm{pH}$ was recorded without selenium (Table 2). Lobos et al. (2016) reported that an increase in irrigation depth lowered concentrations of flavor-related compounds, likely due to a dilution effect of these compounds.

Soluble solids content in the inflorescences was proportional to the severity of drought stress, with the highest values obtained in the $\mathrm{RDI}_{\text {severe }}$ treatment (Table 1). Costa, Ortuño and Chaves, (2007) found that

Table 2: $\mathrm{pH}$, soluble solids, titratable acidity, antioxidant activity by DPPH free radical scavenging (DPPH), antioxidant activity by ferric reducing antioxidant power(FRAP) and total polyphenols in cauliflower inflorescences submitted to selenium application and different irrigation depths.

\begin{tabular}{|c|c|c|c|c|c|c|c|c|c|}
\hline \multirow[b]{2}{*}{$\begin{array}{l}\text { Irrigation } \\
\text { depth }\end{array}$} & \multicolumn{3}{|c|}{$\mathrm{pH}$} & \multicolumn{3}{|c|}{$\begin{array}{c}\text { SOLUBLE SOLIDS } \\
---{ }^{\circ} \text { Brix--- } \\
\end{array}$} & \multicolumn{3}{|c|}{$\begin{array}{c}\text { TITRATABLE ACIDITY } \\
---\% \text {--- } \\
\end{array}$} \\
\hline & $-\mathrm{Se}$ & $+\mathrm{Se}$ & Mean & $-\mathrm{Se}$ & $+\mathrm{Se}$ & Mean & - Se & $+\mathrm{Se}$ & Mean \\
\hline $\mathrm{RDI}_{\text {severe }}$ & $6.37 \mathrm{bA}$ & $6.48 a A$ & 6.42 & 5.83 & 5.95 & $5.71 \mathrm{~A}$ & $2.74 a A$ & $2.46 \mathrm{bA}$ & 2.60 \\
\hline $\mathrm{RDI}_{\text {moderate }}$ & $6.40 \mathrm{aA}$ & $6.42 \mathrm{aAB}$ & 6.41 & 5.51 & 5.11 & $5.31 \mathrm{~B}$ & $2.53 \mathrm{aAB}$ & $2.34 \mathrm{bA}$ & 2.44 \\
\hline No RDI & $6.44 \mathrm{aA}$ & $6.34 \mathrm{bB}$ & 6.39 & 5.32 & 5.31 & $5.32 \mathrm{~B}$ & $2.07 \mathrm{bB}$ & $2.48 \mathrm{aA}$ & 2.27 \\
\hline Mean & 6.41 & 6.41 & 6.41 & $5.34 b$ & $5.55 a$ & 5.45 & 2.43 & 2.45 & 2.44 \\
\hline \multirow[t]{3}{*}{ CV(\%) } & \multicolumn{3}{|c|}{0.70} & \multicolumn{3}{|c|}{3.67} & \multicolumn{3}{|c|}{11.37} \\
\hline & \multirow{2}{*}{\multicolumn{3}{|c|}{$\begin{array}{c}\text { ANTIOXIDANT ACTIVITY } \\
---\% \text { DPPH --- }\end{array}$}} & \multirow{2}{*}{\multicolumn{3}{|c|}{$\begin{array}{c}\text { ANTIOXIDANT ACTIVITY FRAP } \\
--- \text { mg GAE/100g --- } \\
\end{array}$}} & \multirow{2}{*}{\multicolumn{3}{|c|}{$\begin{array}{c}\text { TOTAL POLYPHENOLS } \\
--- \text { mg GAE/100g --- }\end{array}$}} \\
\hline & & & & & & & & & \\
\hline $\begin{array}{l}\text { Irrigation } \\
\text { depth }\end{array}$ & $-\mathrm{Se}$ & $+\mathrm{Se}$ & Mean & - Se & $+\mathrm{Se}$ & Mean & - Se & $+\mathrm{Se}$ & Mean \\
\hline $\mathrm{RDI}_{\text {severe }}$ & $51.85 \mathrm{aB}$ & $42.65 \mathrm{bB}$ & 47.25 & $1.42 \mathrm{aA}$ & $1.33 \mathrm{bB}$ & $1.37 \mathrm{AB}$ & $0.34 \mathrm{bA}$ & $0.46 a \mathrm{~A}$ & 0.40 \\
\hline $\mathrm{RDI}_{\text {moderate }}$ & 56.94aA & $51.48 \mathrm{bA}$ & 54.21 & $1.45 \mathrm{bA}$ & 1.49aA & $1.47 \mathrm{~A}$ & $0.32 \mathrm{bA}$ & $0.49 a A$ & 0.41 \\
\hline No RDI & $54.02 \mathrm{aAB}$ & $41.90 \mathrm{bB}$ & 47.96 & $1.18 \mathrm{bB}$ & $1.24 \mathrm{aAB}$ & $1.21 \mathrm{~B}$ & $0.29 a \mathrm{~A}$ & $0.29 \mathrm{aB}$ & 0.29 \\
\hline Mean & 54.27 & 45.34 & 49.81 & 1.35 & 1.36 & 1.35 & 0.32 & 0.42 & 0.39 \\
\hline CV(\%) & & 14.10 & & & 11.10 & & & 8.67 & \\
\hline
\end{tabular}

*The same lower case letters do not differ for selenium application and the same upper case letters do not differ for irrigation depth according to Tukey's test $(P=0.05)$. (-Se) - without selenium application; (+ Se) foliar spraying of selenium using 100 ppm sodium selenite solution applied three times during the growth cycle; $\mathrm{RDI}_{\text {severe }}$ - severe regulated drought irrigation (50\% $\mathrm{ETc}$ ); $\mathrm{RDI}_{\text {moderate }}$ - moderate regulated drought irrigation (75\% ETc); No RDI - no water restrictions (100\% ETc). 
deficit irrigation produced fruiting vegetables with better flavor and color intensity. Lobos et al. (2016) recorded higher soluble solids concentrations in blueberries submitted to more severe drought stress, possibly due to osmotic adjustment. In plants, soluble solids tend to increase under drought stress in order to reduce osmotic potential and thereby mitigate the effects of drought on development (Nawaz et al., 2015).

Titratable acidity was higher under drought stress, regardless of its severity, when selenium was applied. No differences were observed between irrigation treatments with selenium application (Table 2). With respect to the effect of selenium for each irrigation depth, titratable acid was higher under drought irrigation when selenium was used.

Antioxidant activity was higher under moderate than severe RDI, suggesting that oxidative damage exceeded the ability of the plant's antioxidant system under severe drought stress. Fan et al. (2014) showed a correlation between water deficit and antioxidant enzymes. These authors observed an increase in the activity of enzymes such as SOD, CAT, POX and APX depending on the duration and intensity of the water deficit. They found that greater ROS production during severe drought stress is not always accompanied by a rise in antioxidant enzymes. In blueberries, Lobos et al. (2016) also observed less antioxidant activity under severe drought stress, with irrigation at $75 \%$ ETc positively affecting the stored fruit, suggesting that deficit irrigation could enhance the health benefits of fruit consumption.

Higher concentrations of total polyphenols were recorded when selenium was added under drought irrigation, irrespective of intensity; however, there was no difference between irrigation depths for this variable without the element (Table 2). Analysis of the effect of selenium at each irrigation depth showed greater polyphenol concentrations under drought stress when selenium was applied. According to Jozwiak et al. (2019), selenium addition in cucumber roots also promoted higher bioactive compound levels under drought stress.

Better firmness was observed at the start of storage (0 days) for the normal irrigation treatment (no RDI) with selenium foliar spraying (Figure 1B). At 15 and 20 days of storage, the firmest inflorescences were obtained under severe RDI with selenium application. Lobos et al. (2016) also reported that blueberry firmness differed according to irrigation treatments, with firmer fruits under more severe drought stress $(50 \%$ ETc), followed by $75 \%$ ETc, and the least firm under optimal irrigation (100\% ETc). Fruit size, determined by cell size and number and size of cells, is generally negatively correlated with firmness. Small fruits are typically firmer than large ones because, although both contain a similar number of cells, a large percentage of the former's volume is cell wall material, resulting in denser tissue and firmer fruit (Bryla; Strik, 2007).

In an experiment conducted by Zaicovski et al. (2008), preharvest drought stress improved the postharvest quality of broccoli, with better retention of green color in the floret and a longer shelf life, likely due to greater cytokinin biosynthesis. According to the authors, reducing the irrigation depth may enhance antioxidant activity and help preserve compounds beneficial to human health, such as chlorophylls, carotenoids, phenolic compounds, ascorbic acid and folates.

In general, inflorescences were $14 \%$ firmer in the $\mathrm{RDI}_{\text {severe }}$ treatment with selenium application. Plants raise cytokinin production under drought stress, which delays the senescence of plant organs (Costa et al., 2005). Root growth and cytokinin synthesis increase under low water availability since the roots are the primary site for synthesis and translocation of the hormone to different parts of the plant via the xylem (Hirose et al., 2008).

Similarly to the effect of drought stress, selenium application contributed to floret firmness (Figure 1). Pezzarossa et al. (2012) found that selenium improved flesh firmness in peaches, which they attributed to the decline in ethylene biosynthesis. Malorgio et al. (2009) also reported low ethylene production in lettuce treated with selenium. According to the authors, in plants selenium is incorporated into methionine, forming selenomethionine (SeMet), which reduces free methionine, the initial substrate of ethylene biosynthesis. This explains the low ethylene production in seleniumenriched plants, which therefore have a longer shelf and better postharvest quality.

As storage time progressed, weight loss was lower in florets grown under severe RDI than in fully irrigated plants (100\% ETc) (Figure 1B). After 20 days of storage, weight loss was 37 and $24 \%$ lower under RDI severe $_{\text {treatment }}$ when compared to irrigation with no RDI and moderate RDI (Figure 1B).

Weight loss may be directly related to soluble solids content. Plants submitted to drought stress activate different mechanisms to overcome its harmful effects. These include increasing the concentration of soluble solids in tissues in order to reduce cell osmotic potential and water loss (Nawaz et al., 2015). 
With respect to the influence of selenium application on weight loss, it declined even further with foliar spraying of the element under severe RDI (Figure 1B). Lobos et al. (2016) found that blueberries submitted to drought stress lost less mass than those irrigated at $100 \%$ ETc. Cauliflower grown under severe regulated drought irrigation $(50 \%$ ETc) exhibited high soluble solids concentrations and inflorescence firmness, but low antioxidant activity. Given the need to improve the efficiency of production systems, a promising result was that cauliflower grown under moderate RDI (75\% ETc) produced superior quality florets (firmness, titratable acidity, soluble solids and antioxidant activity) than fully irrigated plants, albeit with similar quality.
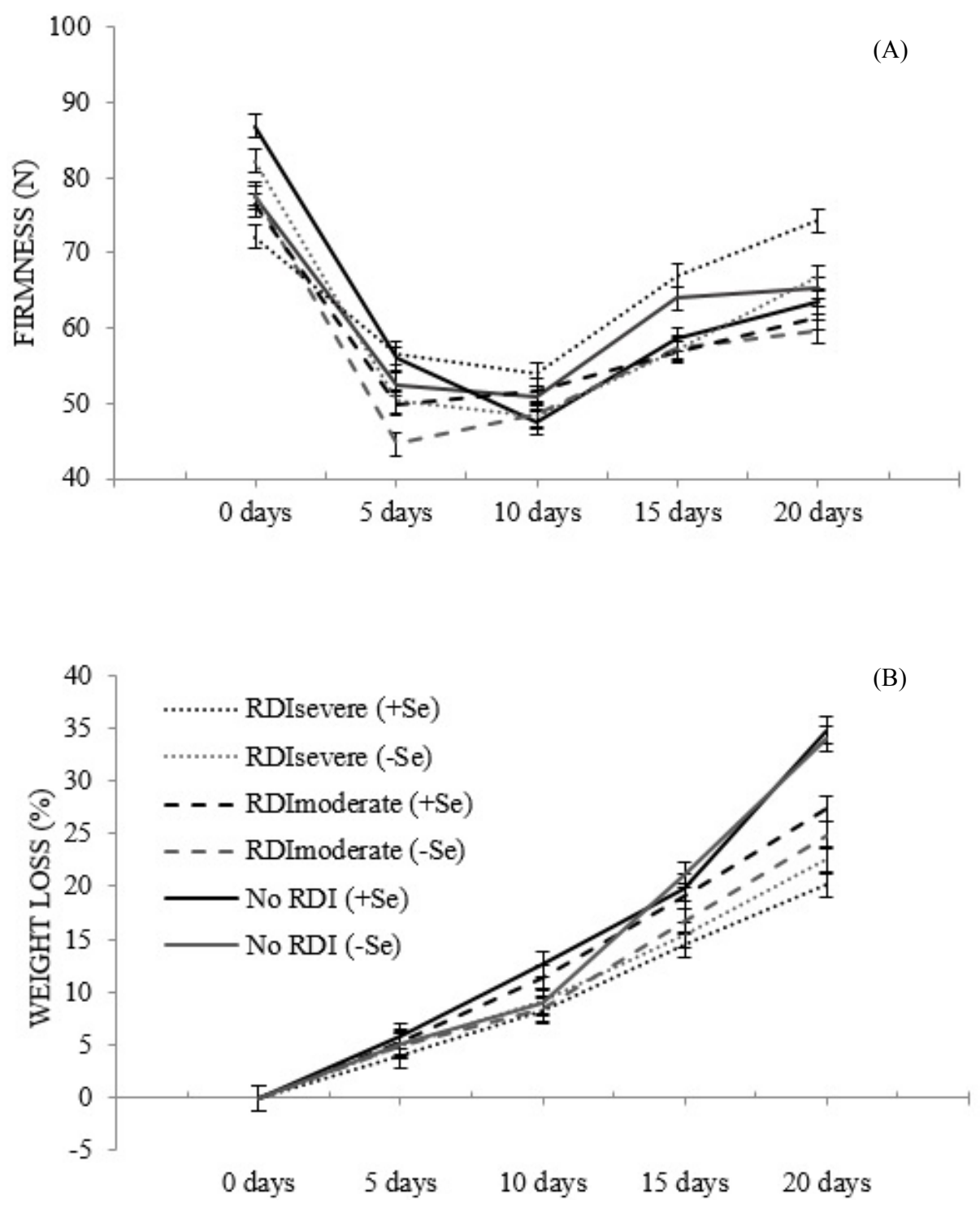

Figure 1: (A) Firmness and (B) Weight loss of cauliflower florets under different irrigation depths and selenium application. (-SE) - without selenium application; (+ SE) foliar spraying of selenium using 100 sodium selenite solution applied three times during the growth cycle; $\mathrm{RDI}_{\text {severe }}$ - severe regulated drought irrigation (50\% $\left.\mathrm{ETc}\right)$; $\mathrm{RDI}_{\text {moderate }}$ - moderate regulated drought irrigation (75\% ETc); No RDI - no water restrictions (100\% ETc). 
Improving quality, maintaining yield and optimizing resources are the basic premises of a more efficient production system. Future studies should investigate different selenium doses under severe drought stress. In the present study, we obtained inflorescences with a longer shelf life, albeit exhibiting some inferior quality traits. In light of the complex interaction between selenium and the environment, additional research is needed to improve other postharvest characteristics.

\section{CONCLUSIONS}

Under the conditions studied and considering the methods and equipment used, the following conclusions could be drawn: Selenium application increased cauliflower yield under moderate RDI (75\% ETc) and no drought stress $(100 \%$ ETc). Moderate RDI (75\% ETc) was the most effective strategy for maintaining yield and increasing the antioxidant capacity and phenolic compound content of cauliflowers. Foliar spraying of selenium raised total polyphenol content under drought stress. Severe RDI ( $50 \%$ ETc) extended the shelf life of cauliflower florets.

\section{REFERENCES}

BOGALE, A. et al. Regulated deficit irrigation and partial root-zone drying irrigation impact bioactive compounds and antioxidant activity in two select tomato cultivars. Scientia Horticulturae, 21(3):115-124, 2016.

BRAND-WILLIAMS, W.; CUVELIER, M. E.; BERSET, C. Use of free radical method to evaluate antioxidant activity. Lebensmttel-Wissenschaft Technologie, 22(1):25-30, 1995.

BRYLA, D. R.; STRIK, B. C. Effects of cultivar and plant spacing on the seasonal water requirements of highbush blueberry. Journal of the American Society for Horticultural Science, 132(2):270-277, 2007.

$\mathrm{CHAl}$, Q. et al. Regulated deficit irrigation for crop production under drought stress - A review. Agronomy for Sustainable Development, 36(3):1-21, 2016.

CIRILLO, C. et al. The influence of deficit irrigation on growth, ornamental quality, and water use efficiency of three potted Bougainvillea genotypes grown in two shapes. HortScience, 49(10):1284-1291, 2014.

COSTA, J. M.; ORTUÑO, M. F.; CHAVES, M. M. Deficit irrigation as a strategy to save water: Physiology and potential application to horticulture. Journal of Integrative Plant Biology, 49(10):1421-1434, 2007.

COSTA, M. L. et al. Effect of ethephon and 6-benzylaminopurine on chlorophyll degrading enzymes and a peroxidase-linked chlorophyll bleaching during postharvest senescence of broccoli (Brassica oleracea L.) at 20 degrees C. Postharvest Biology Technology, 35(2):191-199, 2005.

FAN, H. F. et al. Effect of short-term water deficits stress on antioxidative systems in cucumber seedlings roots. Botanical Studying, 55(46):1-7, 2014.

FERREIRA, D. F. Sisvar: A computer statistical analysis system. Ciência e Agrotecnologia, 35(6):1039-1042, 2011.

FINLEY, J. W. et al. Selenium enrichment of broccoli: Interactions between selenium and secondary plant compounds. Journal of Nutrition, 135(5):1236-1238, 2005.

FOLIN, O.; CIOCALTEU, V. On tyrosine and tryptophane determinations in proteins. Journal of Biological Chemistry, 73(2):627-650, 1927.

HIROSE, N. et al. Regulation of cytokinin biosynthesis, compartmentalization and translocation. Journal of Experimental Botany, 59(1):75-83, 2008.

HABIBI, G. Effect of drought stress and selenium spraying on photosynthesis and antioxidant activity of spring barley. Acta Agriculturae Slovenica, 101(1):31-39, 2013.

INSTITUTO ADOLFO LUTZ. Métodos físico-químicos para análise de alimentos. São Paulo: Instituto Adolfo Lutz, 2008. 1020p.

JOZWIAK, W. et al. Effect of selenium on alleviating oxidative stress caused by a water deficit in cucumber roots. Plants, 8(217):1-18, 2019.

LOBOS, T. E. et al. Pre-harvest regulated deficit irrigation management effects on post-harvest quality and condition of $V$. corymbosum fruits cv. Brigitta. Scientia Horticulturae, 207:152-159, 2016.

MALORGIO, F. et al. Effects of selenium addition on minimally processed leafy vegetables grown in a floating system. Journal of the Science of Food and Agriculture, 89(13):2243-2251, 2009.

NAWAZ, F. et al. Effect of selenium foliar spray on physiological and biochemical processes and chemical constituents of wheat under drought stress. Ecotoxicology and Environmental Safety, 113:191-200, 2015. 
PEZZAROSSA, B. et al. Effects of foliar and fruit addition of sodium selenate on selenium accumulation and fruit quality. Journal of the Science of Food and Agriculture, 92(4):781-786, 2012.

PAULINO, J. et al. Situação da agricultura irrigada no Brasil de acordo com o censo agropecuário 2006. Irriga, 16(2):163176, 2011.

PRETTY, J. et al. Global assessment of agricultural system redesign for sustainable intensification. Nature Sustainability, 1(8):441-446, 2018.

$\mathrm{RHO}, \mathrm{H}$. et al. Limitation factors for photosynthesis in "Bluecrop" highbush blueberry (Vaccinium corymbosum) leaves in response to moderate water stress. Journal of Plant Biology, 55(6):450-457, 2012.

RÍOS, J. J. et al. Biofortification of Se and induction of the antioxidant capacity in lettuce plants. Scientia Horticulturae, 116(3):248-255, 2008.

ROMERO-TRIGUEROS, C. et al. Effect of deficit irrigation and reclaimed water on yield and quality of grapefruits at harvest and postharvest. Food Science and Technology, 85:405-411, 2017.

SARAIVA, B. R. et al. Effect of yerba mate (Ilex paraguariensis A. St.-Hil.) addition on the functional and technological characteristics of fresh cheese. Journal of Food Science and Technology, 56(3):1256-1265, 2019.

SATTAR, A. et al. Physiological and biochemical atributes of bread wheat (Triticum aestivum L.) seedlings are influenced bt foliar application of silicone and selenium under water déficit. Acta Physiologiae Plantarum, 41(146):1-11, 2019.

SCHIAVON, M. et al. Selenium fertilization alters the chemical composition and antioxidant constituents of tomato. Journal of Agricultural and Food Chemistry, 61(44):10542-10554, 2013.
SCHREINER, M. et al. Current understanding and use of quality characteristics of horticulture products. Scientia Horticulturae, 163:63-69, 2013.

SEIDEL, S. J. et al. Impact of irrigation on plant growth and development of white cabbage. Agricultural Water Management, 187:99-111, 2017.

SIEPRAWSKA, A.; KORNAŚ, A.; FILEK, M. Involvement of selenium in protective mechanisms of plants under environmental stress conditions - Review. Acta Biologica Cracoviensia Series Botanica, 57(1):9-20, 2015.

SINGLETON, V. L.; ORTHOFER, R.; LAMUELA, R. M. Analysis of total phenols and other oxidation substrates and antioxidants by means of Folin-Ciocalteau reagente. Methods of Enzymology, 299:152-178, 1999.

TRANI, P. E. et al. Hortaliças. In: RAIJ, B. VAN. et al. (Ed). Recomendações de calagem e adubação para o Estado de São Paulo. 2 ed. Campinas: Instituto Agronômico/ Fundação IAC, 1996.175p.

XU, C.; LESKOVAR, D. I. Growth, physiology and yield responses of cabbage to deficit irrigation. Horticultural Science, 41(3):138-146, 2014.

ZAICOVSKI, C. B. et al. Water stress increases cytokinin biosynthesis and delays postharvest yellowing of broccoli florets. Postharvest Biology and Technology, 49(3):436-439, 2008.

ZEGBE, J. A.; BEHBOUDIAN, M. H.; CLOTHIER, B. E. Responses of 'Petopride' processing tomato to partial rootzone drying at different phenological stages. Irrigation Science, 24(1):203-210, 2006.

ZHU, Q. Y. et al. Antioxidative activities of oolong tea. Journal of Agriculture and Food Chemistry, 50(23):6929-6934, 2002.

WANG, C. et al. Mechanism of exogenous selenium alleviates cadmium induced toxicity in Bechmeria nivea (L.) Gaud (Ramie). Transactions of Nonferrous Metals Society of China, 24(12):3964-3970, 2014. 